\title{
Comparative Analysis of the Bacterial Membrane Disruption Effect of Two Natural Plant Antimicrobial Peptides
}

\author{
Attila Farkas, Gergely Maróti ${ }^{*}$, Attila Kereszt and Éva Kondorosi \\ Institute of Biochemistry, Biological Research Center of the Hungarian Academy of Sciences, Szeged, Hungary
}

In the Medicago truncatula genome about 700 genes code for nodule-specific cysteinerich (NCR) small peptides that are expressed in the symbiotic organ, the root nodule, where they control terminal differentiation of the endosymbiotic rhizobium bacteria to nitrogen-fixing bacteroids. Cationic NCR peptides were predicted to have antimicrobial activities. Here antibacterial activities of NCR247, NCR335, polymyxin B (PMB), and streptomycin were investigated and compared on two foodborne pathogens Salmonella

OPEN ACCESS

Edited by:

Octavio Luiz Franco,

Universidade Católica de Brasilia,

Brazil

Reviewed by:

Osmar Nascimento Silva, Universidade Católica Dom Bosco,

Brazil

Diana Gaspar

Universidade de Lisboa, Portugal

*Correspondence:

Gergely Marót

maroti.gergely@brc.mta.hu

Specialty section:

This article was submitted to

Antimicrobials, Resistance,

and Chemotherapy,

a section of the journal

Frontiers in Microbiology

Received: 07 November 2016

Accepted: 09 January 2017

Published: 23 January 2017

Citation:

Farkas A, Maróti G, Kereszt A and

Kondorosi É (2017) Comparative

Analysis of the Bacterial Membrane Disruption Effect of Two Natural Plant

Antimicrobial Peptides.

Front. Microbiol. 8:51.

doi: 10.3389/fmicb.2017.00051 enterica and Listeria monocytogenes as representatives of Gram-negative and Grampositive bacteria. The integrity of the bacterial membrane was seriously compromised by these NCR peptides. Different localization was observed for NCR247 and NCR335 in the treated bacteria, the peptides mostly accumulated in the cytosol in S. enterica while they remained in the bacterial membrane in $L$. monocytogenes. Scanning electron microscopy revealed distinct membrane morphology of the peptide-treated bacteria. Complete cell disruption was induced by PMB and NCR335 in S. enterica while NCR247 treatment resulted in extensive budding observed on the cell surface of Salmonella. PMB had no effect on L. monocytogenes while NCR335 and NCR247 provoked morphological changes on this bacterium, the whole Listeria cell content was released in response to NCR335 treatment.

Keywords: nodule-specific cysteine-rich plant peptides (NCRs), antimicrobial effect, membrane disruption, foodborne pathogens, peptide localization

\section{INTRODUCTION}

Antimicrobial peptides (AMPs) are considered as natural antibiotics produced by all kinds of living organisms including bacteria (Joerger, 2003; Hassan et al., 2012), plants (Benko-Iseppon et al., 2010), and animals (Hancock and Scott, 2000). Hundreds of AMP molecules have been isolated from prokaryotes to humans and plants (Maróti et al., 2011). They represent a cornerstone of the innate immune system in higher eukaryotes. Different AMPs show variations in their antimicrobial activity spectrum which ranges from Gram-positive and Gram-negative bacteria (including multidrug resistant pathogens) to viruses and fungi. AMPs are in use for hundreds of millions of years in nature and yet they have remained effective (Zasloff, 2002) suggesting that development of resistance against AMPs is moderate. However, experimental evolution has demonstrated the capability of bacterial populations to evolve resistance to AMP drugs (Perron et al., 2006). Insights into AMPs natural environment and their possible natural roles have shown 
that these peptides protect the host against pathogenic microorganisms and are also responsible for fine-balancing interactions with commensal and symbiotic bacterial populations and thus they enhance bio-diversity in microbial communities (Maróti et al., 2011).

The antimicrobial activities and mechanisms of AMPs are diverse. Cationic AMPs can interact with electronegative bacterial cell surface resulting either in cell lysis or disruption of bacterial membrane leading to transient pore formation and peptide transport inside the cell (Epand and Vogel, 1999; Jenssen et al., 2006). AMPs can have multiple intracellular targets when entering the cells. They can associate with nucleic acids, proteins or lipids and inhibit DNA, RNA, protein or cell wall synthesis (Ganz, 2003; Brogden, 2005; Hancock and Sahl, 2006; Hale and Hancock, 2007). Particular AMP targets include DNA gyrase, the heat-shock protein DnaK, the peptidoglycan precursor lipid II and even ATPase (Brogden, 2005; Hasper et al., 2006; Hilpert et al., 2010; Sass et al., 2010). AMPs were also reported to interfere with the cell cycle of fungal cells (Lobo et al., 2007).

Plants represent an extremely abundant and largely unexplored source of AMPs. The recent development of powerful high-throughput genomic techniques has disclosed the presence of large numbers, often even several hundreds of AMPlike genes in various plant genomes (Manners, 2007) indicating the importance of AMPs in the eukaryotes and particularly in plants. The innate immune system is a generic defense response of plants to keep off invading microbes and AMPs are essential part of it. AMPs can be expressed constitutively in specific plant organs or induced by microbes both at the site of infection and systemically (Sels et al., 2008). Interestingly, most of the AMPs are cysteine-rich including defensins, thionins, and cyclotides (Silverstein et al., 2007).

Symbiosis is a ubiquitous phenomenon on Earth, microbial symbionts inhabit various parts of most multicellular species and engage in both beneficial and harmful partnerships. Rhizobium-legume symbioses represent excellent models to study the transitions between mutualistic, parasitic, and freeliving lifestyles. Legumes are unique in their ability to establish symbiotic interactions with rhizobium bacteria and to develop a new organ, the nitrogen-fixing root nodule. In certain species, inside the plant cells the bacteria are irreversibly converted to polyploid, non-dividing nitrogen-fixing bacteroids with altered properties of the cell envelope (Mergaert et al., 2006; Kondorosi et al., 2013). Terminal differentiation of bacteroids is controlled by symbiosis specific plant peptides in inverted repeat-lacking clade (IRLC) legumes (Mergaert et al., 2003; Alunni et al., 2007; Nallu et al., 2014). In the Medicago truncatula genome close to 700 genes code for nodule-specific cysteine-rich (NCR) peptides. The NCR peptides are composed of a relatively conserved signal peptide and a highly variable $20-50$ amino acid long secreted peptide with four or six conserved cysteine residues. Due to the difference in amino acid composition, NCR peptides can be cationic, neutral, or anionic. NCRs resemble in their structure to defensins, the major class of plant AMPs and even certain cationic NCR peptides possess strong antimicrobial activity in vitro (Van de Velde et al., 2010; Tiricz et al., 2013; Ördögh et al., 2014).
The NCR genes are exclusively expressed in the rhizobiuminfected nodule cells, however, different sets of NCRs are induced during the progressive differentiation program of the symbiotic cells (Roux et al., 2014). It was demonstrated that the synthetic cationic NCR247 and NCR335 peptides provoke fast killing of various bacteria and fungi and thereby they are efficient natural antimicrobials (Tiricz et al., 2013; Farkas et al., 2014; Ördögh et al., 2014). As cationic peptides can interact with the negatively charged bacterial membranes our study focused on the membrane disruptive effect of NCR247 and NCR335 on two pathogenic bacterium strains, the Gram-negative Salmonella enterica and the Gram-positive Listeria monocytogenes. The effects of these symbiotic peptides were compared to those of two classical antibiotics, the prokaryotic translation inhibitor streptomycin (STM) and polymyxin B (PMB), a cyclic peptide antibiotic.

\section{MATERIALS AND METHODS}

\section{In silico Peptide Analysis}

Two different antimicrobial peptide predictor tools were used; the Antimicrobial Peptide Database with APD3 algorithm: Antimicrobial Peptide Calculator and Predictor http://aps.unmc. edu/AP/ (Wang et al., 2016) and the AMP predictor tool of the Collection of Anti-Microbial Peptides (CAMP) (Thomas et al., 2009). The latter operates with four different prediction models taking into account the sequence composition, physico-chemical properties, and structural characteristics of amino acids; Support Vector Machine (SVM), Random Forest (RF), Artificial Neural Network (ANN), and Discriminant Analysis (DA) (Waghu et al., 2014). As a result, SVM, RF, and DA models give a probability score (between 0 and 1) (Waghu et al., 2016). Higher score means greater possibility for the peptide to exert antimicrobial activity. AMP: the sequence predicted to be antimicrobial. NAMP: the sequence predicted to be not antimicrobial.

\section{Microbial Strains and NCR Peptides}

Salmonella enterica serovar Enteritidis (ATCC 13076) and L. monocytogenes (ATCC 19111) were purchased from validated culture collections. NCR247 and NCR335 were synthesized by conventional solid phase peptide synthesis at $>95 \%$ purity, synthesis was done by ProteoGenix SAS (France), vendor provided data of peptide characterization including HPLC and Mass Spectrometry data.

\section{Determination of the Minimal Inhibitory Concentration (MIC) and Minimal Bactericidal Concentration (MBC) Using Broth Resazurin Microdilution Assay}

A single colony from both strains were grown in Mueller Hinton Broth (MHB) at $37^{\circ} \mathrm{C}$ overnight. The starter cultures were diluted and grown until $\mathrm{OD}_{600}=0.5-1.0$. The number of colonyforming units was determined, the dilution factors necessary for performing the MIC tests were calculated and the dilutions were made to obtain cultures with $5 \times 10^{6} \mathrm{cfu} / \mathrm{mL}$. Plates were 
prepared under aseptic conditions. A sterile 96-well plate was labeled. A volume of $90 \mu \mathrm{L}$ of sterile MHB was pipetted into each well of first row of the plate, these wells served as negative controls. Fifty microliters MHB was added to all other wells. Twofold dilution series of the NCR247, NCR335, PMB, and STM were prepared $(0.1,0.5,1,2,4,8,16,32,64$, and $128 \mu \mathrm{M})$ and added to the wells. Ten microliters of resazurin indicator solution ( $0.1 \%$ diluted in MHB) was added into each well. Finally, $10 \mu \mathrm{L}$ of bacterial suspension $\left(5 \times 10^{6} \mathrm{cfu} / \mathrm{mL}\right)$ was added to each well to achieve a concentration of $5 \times 10^{5} \mathrm{cfu} / \mathrm{mL}$. The plates were prepared in triplicate and incubated at $37^{\circ} \mathrm{C}$ for $20 \mathrm{~h}$. The color change was then assessed visually. Any color changes from purple to pink or colorless were recorded. The lowest peptide/PMB/STM concentration at which color change occurred was considered as the MIC value (Wiegand et al., 2008; Balouiri et al., 2016). For the determination of MBC, $100 \mu \mathrm{L}$ cultures were plated from the wells that exhibited no growth. The plates were incubated at $37^{\circ} \mathrm{C}$ for $24 \mathrm{~h}$. The lowest concentration where no bacterial growth was detected was considered as MBC (Kang et al., 2011).

\section{Determination of the Complete Elimination Concentrations (CE Values) Using Drop Plate Method}

Both strains were grown in $10 \mathrm{~mL}$ of liquid Luria Broth (LB) at $37^{\circ} \mathrm{C}$ overnight, then the starter cultures were diluted in $10 \mathrm{~mL} \mathrm{LB}$ to $\mathrm{OD}_{600}=0.05$ and grown until mid-logarithmic phase $\left(\mathrm{OD}_{600}=0.5-0.8\right)$. The optical density was set to $\mathrm{OD}_{600}=0.1$ in $20 \mathrm{mM}$ potassium phosphate buffer, $\mathrm{pH} 7.2$ (PB) for the antimicrobial tests. For $S$. enterica, the $\mathrm{OD}_{600}$ of 0.1 represents $8.25 \times 10^{7} \mathrm{CFU} / \mathrm{mL}$, for L. monocytogenes $3.07 \times 10^{9}$. The antimicrobial activities were determined according to the guidelines of the drop plate method (Herigstad et al., 2001; Chen et al., 2003). Peptides were serially diluted in $\mathrm{PB}$ buffer. Fifty microliter $(\mu \mathrm{L})$ of bacterial culture was mixed with $50 \mu \mathrm{L}$ NCR peptide/STM/PMB applied at 0.5 , $2.5,5,10,25$, and $50 \mu \mathrm{M}$ final concentrations followed by incubation at room temperature for $2 \mathrm{~h}$ without shaking. Treated bacteria were dropped on LB agar plates. The drops were absorbed to agar in less than a half an hour and the plates were incubated at inverted position at $37^{\circ} \mathrm{C}$ overnight. Three independent experiments were performed in all cases.

\section{Membrane Permeability Assay}

Cytoplasmic membrane damage was assayed with the Live/Dead BacLight bacterial viability kit (Invitrogen L7012) according to the manufacturer's instructions (Horváth et al., 2015). Bacteria (S. enterica and L. monocytogenes) were grown to mid-logarithmic phase and the optical density was set to $\mathrm{OD}_{600}=0.1$ in LB and washed gently with PB buffer. Bacterial cells resuspended in PB buffer were treated with $10 \mu \mathrm{M}$ NCR247, $5 \mu \mathrm{M}$ NCR335, and $5 \mu \mathrm{M}$ PMB at room temperature for $60 \mathrm{~min}$. Untreated cells served as negative control. Then the cells were stained with $7.5 \mu \mathrm{M}$ SYTO-9 and $30 \mu \mathrm{M}$ propidium iodide (PI). After $15 \mathrm{~min}$ incubation in dark the cells $(5 \mu \mathrm{L})$ were spotted on microscope slide and covered with $2 \%$ (w/v) agar slices and observed with Olympus Fluoview FV 1000 confocal laser microscope with $60 \times$ magnification objective. $488 \mathrm{~nm}$ laser was used for excitation, and emission was detected at 500-530 nm for SYTO9. Excitation and emission wavelengths were 543 and 555$655 \mathrm{~nm}$ for PI, respectively. Sequential scanning was used to avoid crosstalk of the fluorescent dyes.

\section{Localization of FITC-Labeled Peptides in Bacteria}

Mid-logarithmic phase bacterial cultures $\mathrm{OD}_{600}=0.1$ were resuspended in PB buffer containing FITC-labeled NCR247 or NCR335 at a concentration corresponding to $0.5 \times \mathrm{CE}$. Following incubation for $30 \mathrm{~min}$ at room temperature, samples were co-stained with 800 nM FM4-64 membrane dye. The stained cells $(5 \mu \mathrm{L})$ were spotted on a microscope slide and covered with $2 \%(\mathrm{w} / \mathrm{v})$ agar slices. Localization of the labeled peptides was observed with Olympus Fluoview FV 1000 confocal laser microscope with $60 \times$ magnification objective (Farkas et al., 2014). $488 \mathrm{~nm}$ laser was used for excitation, and the emission was detected at 500-530 $\mathrm{nm}$ for FITC. Excitation and emission wavelengths for FM4-64 were 543 and 555-655 nm, respectively. Sequential scanning was used to avoid crosstalk of the fluorescent dyes.

\section{Scanning Electron Microscopy (SEM)}

Mid-logarithmic phase bacteria were washed twice with and resuspended in $\mathrm{PB}$ buffer at $\mathrm{OD}_{600}=0.1$. The cells were incubated at room temperature with $0.5 \times \mathrm{CE}$ NCR247 and NCR335 for 5 min and $2 \mathrm{~h}$. Cells were then fixed with $2.5 \%$ (v/v) glutaraldehyde and $0.05 \mathrm{M}$ cacodylate buffer $\mathrm{pH} 7.2$ in phosphate buffered saline (PBS), and post fixed with $0.1 \%$ osmium tetroxide in PBS for $1 \mathrm{~h}$. Five microliters of the above bacterial suspension were spotted on a polycarbonate membrane filter (GTTP $0.2 \mu \mathrm{m}$, Millipore). Thereafter, the filters were washed twice with PBS and dehydrated with a graded ethanol series (30\%, 50\%, 70\%, $80 \%$, and $100 \%$ ethanol, each for $15 \mathrm{~min})$. Untreated bacterial cells handled in the same way served as control. The samples were dried with a critical point dryer, followed by $12 \mathrm{~nm}$ gold coating and observed under a scanning electron microscope (JEOL JSM-7100F/LV).

\section{RESULTS}

\section{In silico AMP Characteristics of Symbiotic NCR247 and NCR335}

Previous works demonstrated antimicrobial activity of NCR247 and NCR335. Their classification as AMPs required indepth analysis of their sequence-based physico-chemical properties, such as peptide length, molecular weight, amino acid composition, hydrophobicity, charge, and Boman index (Table 1). The length parameter influences the insertion ability of peptides into target membranes (Shai, 2002). Both NCR peptides are short, NCR247 is composed of 24 aa, while the active form of NCR335 is 64 aa. Cysteines contribute to the biochemical stability 
TABLE 1 | Physico-chemical properties of NCR247 and NCR335.

NCR247 sequence

NCR335 sequence

RNGCIVDPRCPYQQCRRPLYCRRR

\begin{tabular}{|c|c|c|}
\hline & \\
\hline & NCR247 & NCR335 \\
\hline Amino acid & 24 & 64 \\
\hline Molecular weight & 2991.574 Da & $7718.24 \mathrm{Da}$ \\
\hline Amino acid composition & 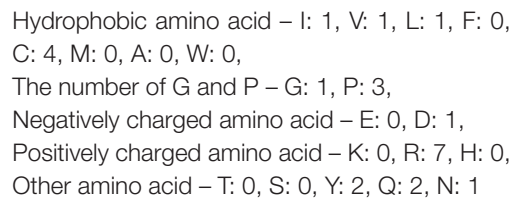 & $\begin{array}{l}\text { Hydrophobic amino acid - I: 3, V: 3, L: } 6, \mathrm{~F}: 4 \text {, } \\
\mathrm{C}: 4 \text {, M: } 2, \mathrm{~A}: 1, \mathrm{~W}: 1 \text {, } \\
\text { The number of G and P - G: 2, P: 3, } \\
\text { Negatively charged amino acid - E: 0, D: } 2, \\
\text { Positively charged amino acid - K: 7, R: } 9, \mathrm{H}: 2 \text {, } \\
\text { Other amino acid - T: 3, S: 3, Y: 1, Q: 2, N: } 6\end{array}$ \\
\hline Hydrophobic ratio & $29 \%$ & $37 \%$ \\
\hline Net charge & +6 & +14 \\
\hline Protein-binding Potential (Boman index) & $4.63 \mathrm{kcal} / \mathrm{mol}$ & $2.88 \mathrm{kcal} / \mathrm{mol}$ \\
\hline
\end{tabular}

The parameters were calculated using the antimicrobial peptide database with APD3 algorithm: Antimicrobial Peptide Calculator and Predictor (http://aps.unmc.edu/AP).

of the molecules by forming disulfide bridges. Both NCR247 and NCR335 have four cysteine residues which form two inter-chain disulfide bridges. High positive net charge provokes interactions with the negatively charged microbial membranes which is another important factor to exert antimicrobial activity (Tossi et al., 2000). NCR335 has one of the highest positive net charge (+14) among all M. truncatula NCRs, while NCR247 has a net charge of +6 . The cationic amino acids lysine $(\mathrm{K})$ and arginine (R) flanked by hydrophobic, membrane-insertive isoleucine (I), valine $(\mathrm{V})$, leucine $(\mathrm{L})$, phenylalanine $(\mathrm{F})$, and alanine (A) residues form amphipathic structure with 29\% and 37\% hydrophobic ratio in NCR247 and NCR335, respectively. The Boman index, which is a hydropathy numeric value, measures peptides affinity to other proteins. The Boman index of NCR247 is $4.63 \mathrm{kcal} / \mathrm{mol}$, which is the highest value among all NCRs (Farkas et al., 2014), while that of NCR335 is $2.88 \mathrm{kcal} / \mathrm{mol}$. The assessment of the physico-chemical properties of NCR247 and NCR335 revealed clear AMP properties. Additionally, all tested AMP prediction tools at the CAMP, such as RF, SVM, ANN, and DA (Thomas et al., 2009) classified NCR247 as AMP with high probability, while NCR335 was recognized as AMP by two of the four models (Table 2).

TABLE 2 | Antimicrobial peptide prediction of NCR247 and NCR335 peptides.

\begin{tabular}{lccc}
\hline & Seq. ID. & Class & AMP probability \\
\hline Support Vector Machine (SVM) classifier & NCR247 & AMP & 0.970 \\
& NCR335 & AMP & 0.858 \\
Random Forest Classifier & NCR247 & AMP & 0.7275 \\
& NCR335 & NAMP & 0.439 \\
Artificial Neural Network (ANN) classifier & NCR247 & AMP & \\
& NCR335 & AMP & \\
Discriminant Analysis classifier & NCR247 & AMP & 0.997 \\
& NCR335 & NAMP & 0.405 \\
\hline
\end{tabular}

All four tested models of the Collection of Anti-Microbial Peptides (CAMP) predictor tool classified NCR247 as AMP with high probability, while NCR335 was recognized as AMP by two of the four models. NAMP refers to non-AMP.

\section{Differential Sensitivity of Bacteria to NCRs and Classical Antibiotics}

Antimicrobial activity of NCR247 and NCR335 peptides against $S$. enterica and $L$. monocytogenes has been investigated and compared to that of two well-characterized antimicrobials, PMB and streptomycin (STM). Two different approaches were applied to characterize the peptides antimicrobial features (Figure 1 and Table 3). The standard MIC, MBC assay using microtiter plates with various concentrations of peptides and antibiotics was used to analyze bacterial growth inhibition. The MIC value obtained for PMB was $0.5 \mu \mathrm{M}$ on $S$. enterica and $128 \mu \mathrm{M}$ for L. monocytogenes (Table 3). The MBC values for $\mathrm{PMB}$ was $1 \mu \mathrm{M}$ on $S$. enterica and higher than $128 \mu \mathrm{M}$ for L. monocytogenes. STM inhibited Salmonella growth at $4 \mu \mathrm{M}$ (MIC) and eliminated all Salmonella bacteria at a threefold greater concentration of $32 \mu \mathrm{M}$ (MBC). STM was not able to inhibit the growth of $L$. monocytogenes up to $128 \mu \mathrm{M}$. The MIC values of NCR247 and NCR335 were 32 and $16 \mu \mathrm{M}$ against S. enterica, respectively. The MBC values for NCR247 and NCR335 on S. enterica were 64 and $16 \mu \mathrm{M}$, respectively. The MIC values of NCR247 and NCR335 were 128 and $32 \mu \mathrm{M}$ against L. monocytogenes, respectively. The MBC value of NCR247 on L. monocytogenes was higher than $128 \mu \mathrm{M}$, while NCR335 had an MBC of $32 \mu \mathrm{M}$ on this Gram-positive pathogen (Table 3).

Using the drop-plate approach $S$. enterica was resistant to STM but was efficiently killed by PMB and NCR335. PMB reduced colony formation already at $0.5 \mu \mathrm{M}$ and at $2.5 \mu \mathrm{M}$ both PMB and NCR335 eliminated all bacteria. NCR247 reduced bacterial growth at $2.5 \mu \mathrm{M}$, but complete elimination (CE) required a peptide concentration of at least $10 \mu \mathrm{M}$ (Figure 1A). Interestingly, L. monocytogenes was fully resistant to both $\mathrm{PMB}$ and streptomycin while showing clear sensitivity to the plant peptides. NCR335 already at $2.5 \mu \mathrm{M}$ killed all bacteria, while NCR247 reduced growth from $10 \mu \mathrm{M}$, nevertheless, even at $50 \mu \mathrm{M}$ the inhibition was not complete (Figure 1B). Based on these data, the CE concentrations for $S$. enterica were $\leq 2.5 \mu \mathrm{M}$ for NCR335 and $\mathrm{PMB}$, while $\geq 10 \mu \mathrm{M}$ for 
A
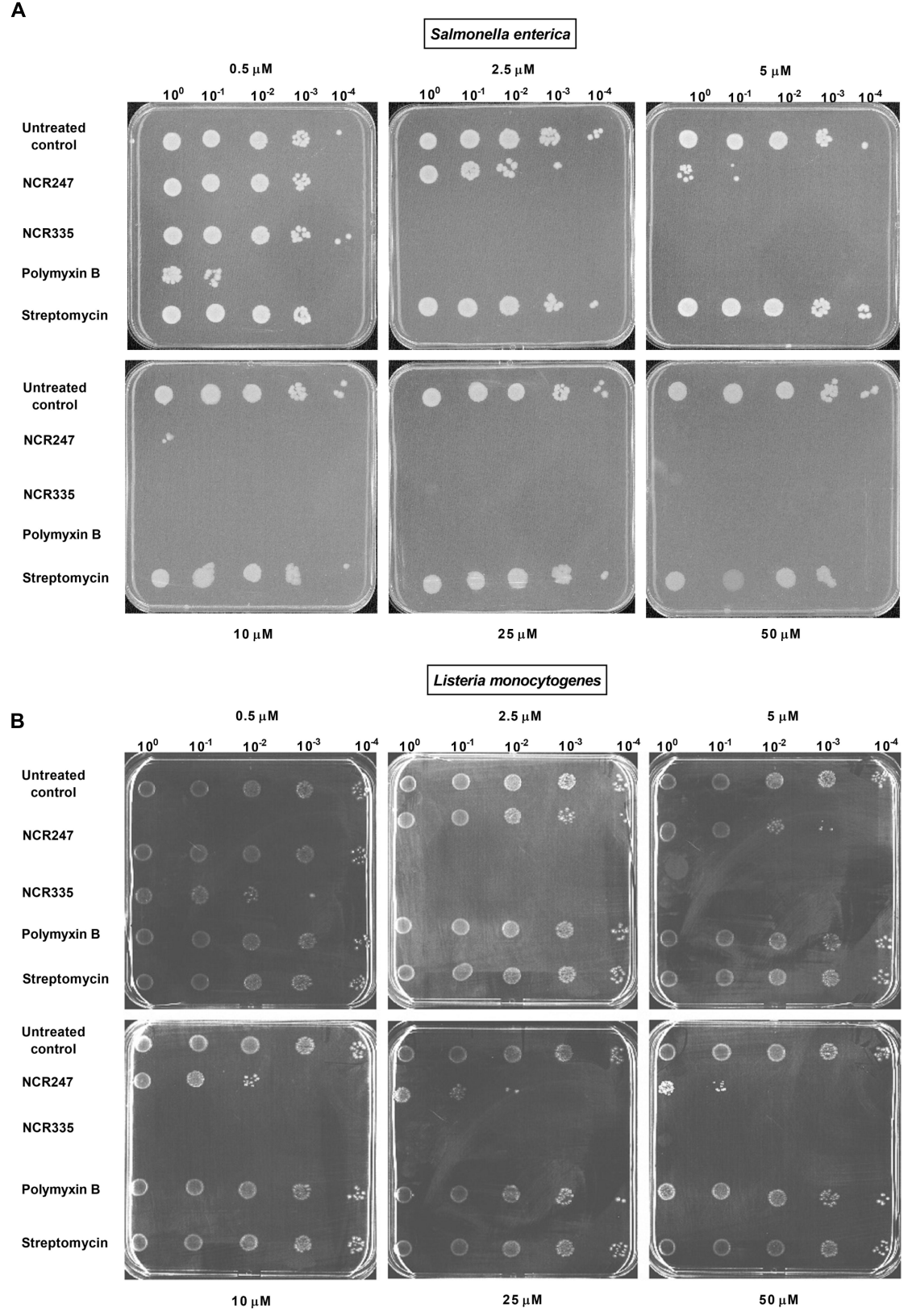

FIGURE 1 | Antimicrobial activity of nodule-specific cysteine-rich (NCR) peptides. (A) Activity against Salmonella enterica. (B) Activity against Listeria monocytogenes. Complete elimination (CE) values of $2.5 \mu \mathrm{M}$ were determined for NCR335 against both $S$. enterica and $L$. monocytogenes. The CE values of NCR247 were $\geq 10 \mu \mathrm{M}$ against $S$. enterica, while L. monocytogenes was less sensitive to this peptide (CE $>50 \mu \mathrm{M})$. L. monocytogenes was fully resistant to both polymyxin $B$ and streptomycin while showed clear sensitivity to the plant peptides.

NCR247. CE for L. monocytogenes was $\leq 2.5 \mu \mathrm{M}$ in the case of NCR335, while CE of NCR247 was more than $50 \mu \mathrm{M}$ (Table 4).

\section{NCR247 and NCR335 Increase Cell Membrane Permeability}

The damage of the bacterial membrane was visualized by costaining of the cells with two fluorescent nucleic acid dyes. The membrane-permeable SYTO-9 stains all bacterial cells and shows green fluorescence. In contrast, propidium iodide (PI) enters only damaged non-living cells and produces red fluorescence. Bacterial cultures of $S$. enterica and L. monocytogenes were incubated for 60 min with $10 \mu \mathrm{M}$ PMB, $10 \mu \mathrm{M}$ NCR247, or $5 \mu$ M NCR335 (0.5 $\times$ CE values), after co-staining with SYTO9 and PI the cells were observed with confocal laser scanning microscopy (CLSM) (Figure 2). The untreated S. enterica and $L$. monocytogenes cells showed only green fluorescence indicating 
that all cells were alive. In contrast, the majority of $S$. enterica cells treated with PMB, NCR247 or NCR335 showed red fluorescence which indicated membrane damage. A significant degree of membrane permeabilization was induced on L. monocytogenes upon the addition of NCR247, while PMB was not able to induce membrane permeabilization on this Gram-positive pathogen. NCR335 provoked, similarly, red fluorescence as a consequence of membrane damage and death of $L$. monocytogenes. The assay clearly showed an increased permeability of both Gramnegative and Gram-positive membranes in response to treatment with NCR247 or NCR335. Furthermore, the results indicated that the bactericidal effect of NCR peptides on $S$. enterica and L. monocytogenes is directly realized through membrane permeabilization and damage.

\section{Localization of FITC-Labeled NCR247 and NCR335}

In addition to the membrane disrupting effects of AMPs at $\geq \mathrm{CE}$, the peptides at lower concentration without membrane disruption can have various intracellular targets as it was shown

TABLE 3 | Minimal inhibitory concentration (MIC) and minimal bactericidal concentration (MBC) of NCR247 and NCR335 on Salmonella enterica and Listeria monocytogenes using broth resazurin microdilution assay.

\begin{tabular}{|c|c|c|c|c|}
\hline \multicolumn{5}{|c|}{ MIC and MBC $(\mu \mathrm{M})$} \\
\hline \multirow[t]{3}{*}{ Peptide/Antibiotics } & \multirow{2}{*}{\multicolumn{2}{|c|}{$\begin{array}{c}\text { Gram-negative } \\
\text { S. enterica }\end{array}$}} & \multirow{2}{*}{\multicolumn{2}{|c|}{$\begin{array}{c}\text { Gram-positive } \\
\text { L. monocytogenes }\end{array}$}} \\
\hline & & & & \\
\hline & MIC & MBC & MIC & MBC \\
\hline NCR247 ( $\mu \mathrm{M})$ & 32 & 64 & 128 & $>128$ \\
\hline NCR335 ( $\mu \mathrm{M})$ & 16 & 16 & 32 & 32 \\
\hline Polymyxin B ( $\mu \mathrm{M})$ & 0.5 & 1 & 128 & $>128$ \\
\hline Streptomycin $(\mu \mathrm{M})$ & 4 & 32 & $>128$ & $\mathrm{NE}$ \\
\hline
\end{tabular}

MIC and MBC values were determined for the NCR peptides and for PMB and STM using a standard, validated method. NE: no effect up to $128 \mu \mathrm{M}$.

TABLE 4 | Complete elimination (CE) concentrations of NCR247 and NCR335 on S. enterica and $L$. monocytogenes using drop plate method.

\begin{tabular}{|c|c|c|}
\hline \multicolumn{3}{|c|}{ Drop plate method } \\
\hline \multirow[t]{3}{*}{ Peptide/antibiotics } & \multicolumn{2}{|c|}{ Concentration of CE } \\
\hline & Gram-negative & Gram-positive \\
\hline & Salmonella enterica & Listeria monocytogenes \\
\hline NCR247 $(\mu \mathrm{M})$ & $\geq 10$ & $>50$ \\
\hline NCR335 $(\mu \mathrm{M})$ & $\leq 2.5$ & $\leq 2.5$ \\
\hline Polymyxin B ( $\mu \mathrm{M})$ & $\leq 2.5$ & NE \\
\hline Streptomycin ( $\mu \mathrm{M})$ & NE & NE \\
\hline
\end{tabular}

NCR247 was active above $10 \mu \mathrm{M}$ against $\mathrm{S}$. enterica and above $50 \mu \mathrm{M}$ against L. monocytogenes. NCR335 killed all the cells on the tested strains at $2.5 \mu \mathrm{M}$. Polymyxin B eliminated all S. enterica cells at a concentration less than $2.5 \mu \mathrm{M}$. L. monocytogenes was fully resistant to polymyxin B. Streptomycin had no effect on the tested bacteria. NE: no effect up to $50 \mu \mathrm{M}$. for NCR247 (Farkas et al., 2014). To test if NCR247 and NCR335 interact only with the bacterial membrane or enter the cytosol, $S$. enterica and L. monocytogenes cells were treated with FITClabeled NCR247 and NCR335 at $0.5 \times$ CE for $30 \mathrm{~min}$ and co-stained with FM4-64 marking the bacterial membranes with red color (Figure 3). Both FITC-NCR247 and FITC-NCR335 showed slow penetration through the Gram-negative $S$. enterica membranes and accumulated in the bacterial cytoplasm. In contrast, the fluorescence of FITC-NCR247 and NCR335 and FM4-64 labels overlapped in L. monocytogenes indicating the membrane localization of NCR247 and NCR335 in this Grampositive pathogen. Overall, the localization results suggested different membrane disruption mechanisms of NCR247 and NCR335 on Gram-positive and Gram-negative bacteria.

\section{NCR247 and NCR335 Causes Distinct Morphological Changes in S. enterica and L. monocytogenes}

Antimicrobial activity of AMPs is usually depending on their positive net charge and their capacity to bind to the negatively charged bacterial membranes. While NCR247 and NCR335 are both cationic their MIC, MBC, and $\mathrm{CE}$ values were significantly different suggesting that in addition to the positive charge their amino acid composition and primary sequence contribute also to their activities and might influence their interaction with the bacterial envelope. Therefore, we studied how the morphology of S. enterica and L. monocytogenes is affected by NCR247, NCR335, and PMB treatments at CE values (Figure 4). Interestingly, NCR247 and NCR335 displayed distinct localization as observed in Figure 3. Scanning electron microscopy (SEM) observation was applied to visualize the distinct morphological changes on the bacterial membranes treated with NCR247 and NCR335. The results showed clear differences in the membrane morphology of the untreated and peptide treated S. enterica and L. monocytogenes. The untreated bacterial membranes were smooth and intact (Figures 4A,E,I,M). S. enterica cells treated with $2.5 \mu \mathrm{M}$ of PMB provoked leaking wrinkly cell surface within $5 \mathrm{~min}$ (Figure 4B) and complete cell lysis after $2 \mathrm{~h}$ (Figure 4F), while even a 10-fold higher concentration of $\mathrm{PMB}$ had no effect on L. monocytogenes. The cells remained intact and showed fairly normal surface either after $5 \mathrm{~min}$ (Figure 4J) and $2 \mathrm{~h}$ incubation (Figure 4N) with $25 \mu \mathrm{M}$ PMB. However, clear changes were observed on $S$. enterica cells treated with $10 \mu \mathrm{M} \mathrm{NCR} 247$ for $5 \mathrm{~min}$, the formation of blebs was observed throughout the Salmonella cell surface (Figure 4C). The effective NCR247 concentration for L. monocytogenes was higher than that for $S$. enterica. L. monocytogenes cells treated with $50 \mu \mathrm{M}$ NCR247 showed leaking rough surface after 5 min treatment indicating the loss of membrane integrity (Figure $4 \mathbf{K}$ ). Furthermore, cell debris accumulated from lysed Listeria cells was observable around the cells when $2 \mathrm{~h}$ treatment was applied (Figure 40). NCR335 treatment for $5 \mathrm{~min}$ at $2.5 \mu \mathrm{M}$ concentration resulted a wrinkled membrane surface on S. enterica (Figure 4D) similar to what was detected in the case of PMB treatment (Figure 4B). L. monocytogenes cells treated with NCR335 for $2 \mathrm{~h}$ at the same 
A

\section{Salmonella enterica}

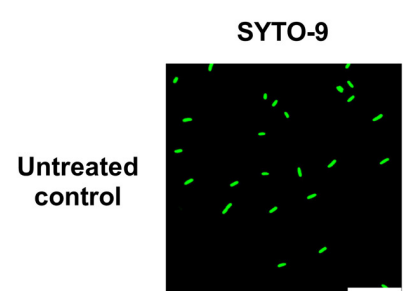

Polymyxin B
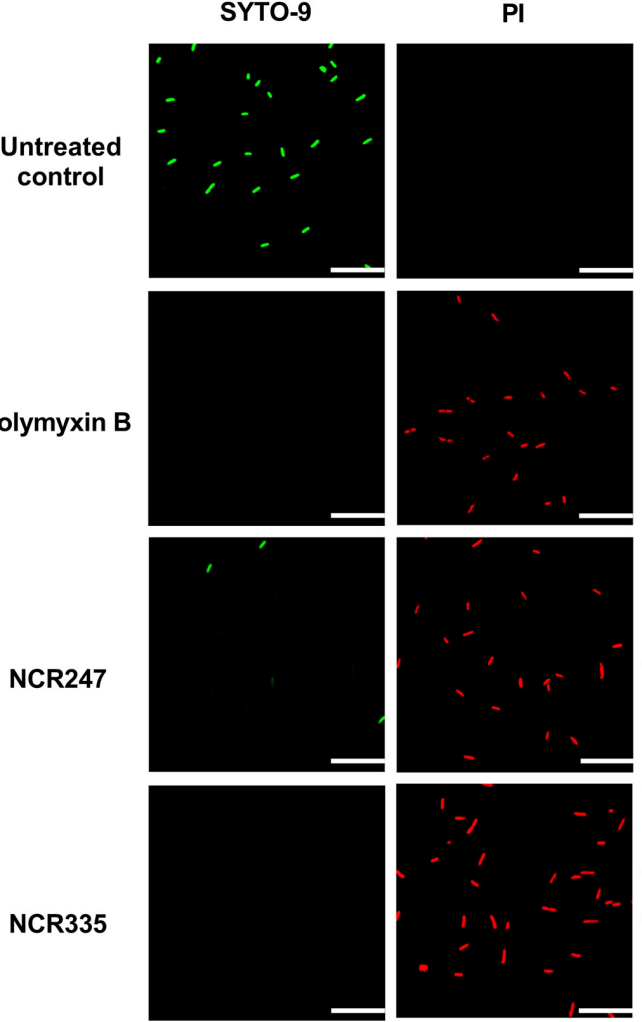

MERGE
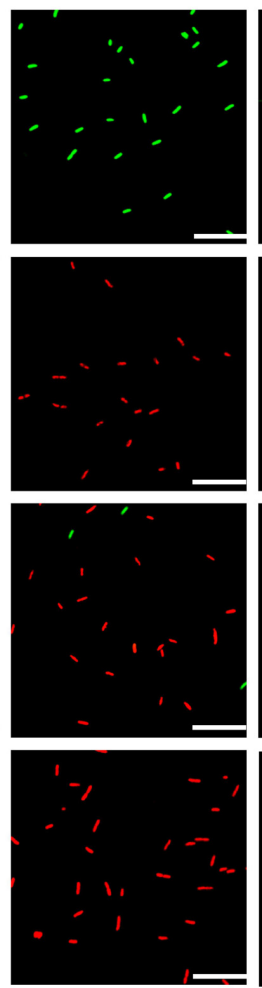

B

Listeria monocytogenes
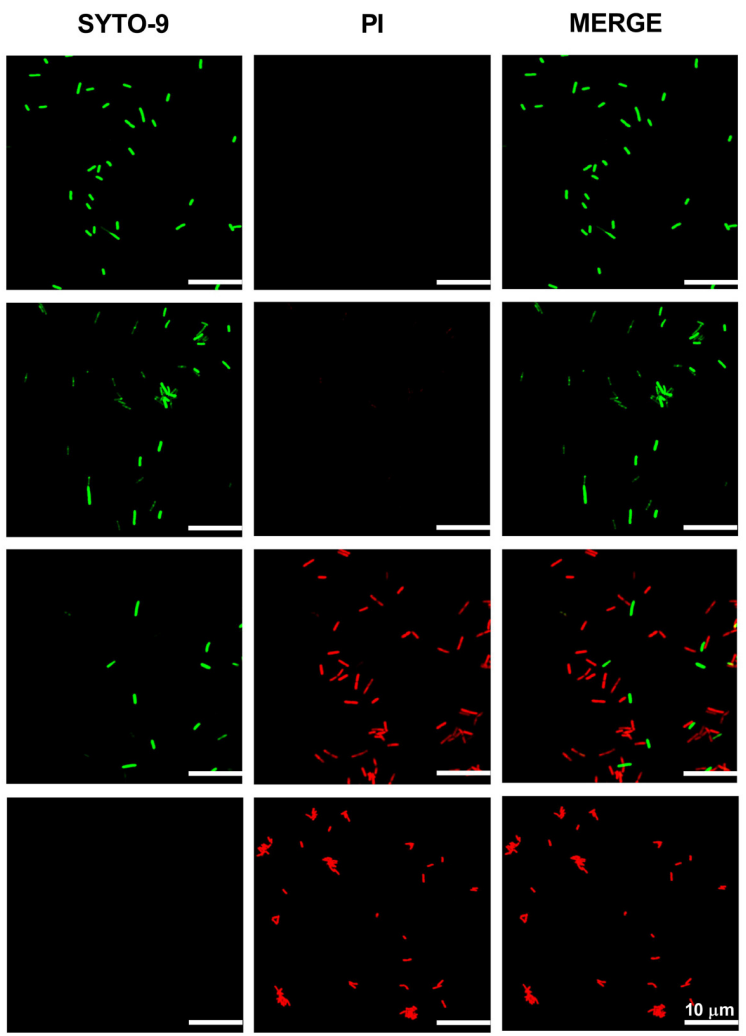

FIGURE 2 | Bacterial membrane integrity is compromised in the presence of NCRs. Fluorescence microscopy images of (A) S. enterica cells and

(B) L. monocytogenes cells treated with $10 \mu \mathrm{M}$ NCR247, $5 \mu \mathrm{M}$ NCR335, and $10 \mu \mathrm{M}$ polymyxin B for $1 \mathrm{~h}$ and stained with SYTO-9 and PI dyes. Green fluorescence indicates unaltered membrane integrity. Red fluorescence indicates membrane disintegration (permeable membrane). Scale bar: $10 \mu \mathrm{m}$.

concentration $(2.5 \mu \mathrm{M})$ provoked a complete loss of osmotic pressure and the cells lysed (Figure 4P). This drastic Listeria cell lysis in response to NCR335 treatment at $2.5 \mu \mathrm{M}$ concentration was in good accordance with the results of the CE tests. The data suggested that both NCRs interacted with both Gram-negative and Gram-positive bacterial membranes and resulted in pore formation leading to cell death.

\section{DISCUSSION}

NCR247 and NCR335 peptides are members of the NCR peptide family discovered in M. truncatula (Mergaert et al., 2003; Nallu et al., 2014). In their natural environment, peptides concentrations of the symbiotic cells are incomparably lower and they alter the morphology and physiology of the endosymbiont bacteria without killing them. Based on physico-chemical AMP properties they primarily act via membrane disruption. However, identification of intracellular targets demonstrated that NCR247 efficiently inhibits bacterial cell division (Farkas et al., 2014). The detailed in silico characterization of these natural plant peptides suggested that NCR247 and NCR335 exerted antimicrobial features which was verified by multiple prediction algorithms and experimental studies. Previous work has shown that NCR247 and NCR335 induced membrane depolarization on cultured S. meliloti (Tiricz et al., 2013).

In this study, the potential antimicrobial activity and the bacterial membrane disruptive effects of NCR247 and NCR335 were tested on two pathogenic bacteria, the Gramnegative $S$. enterica and the Gram-positive L. monocytogenes. Salmonellosis (Löfström et al., 2016) and listeriosis (Lecuit, 2007) are among the most common foodborne diseases in the world, these foodborne pathogens infect human via transfer from animals and animal-derived food products and potentially cause serious diseases. Since these bacteria have the ability to develop resistance to multiple classes of antibiotics it is plausible that certain Salmonella and Listeria strains might evolve toward multiresistance. Novel antimicrobial agents effective against Gram-negative and/or Gram-positive pathogens are of high interest to develop efficient future treatments. AMPs represent a diverse group of synthetic and natural molecules with real potential to become effective future drugs as peptide antibiotics. A number of AMPs (mostly cationic ones) were shown to display remarkable antibacterial activities. 


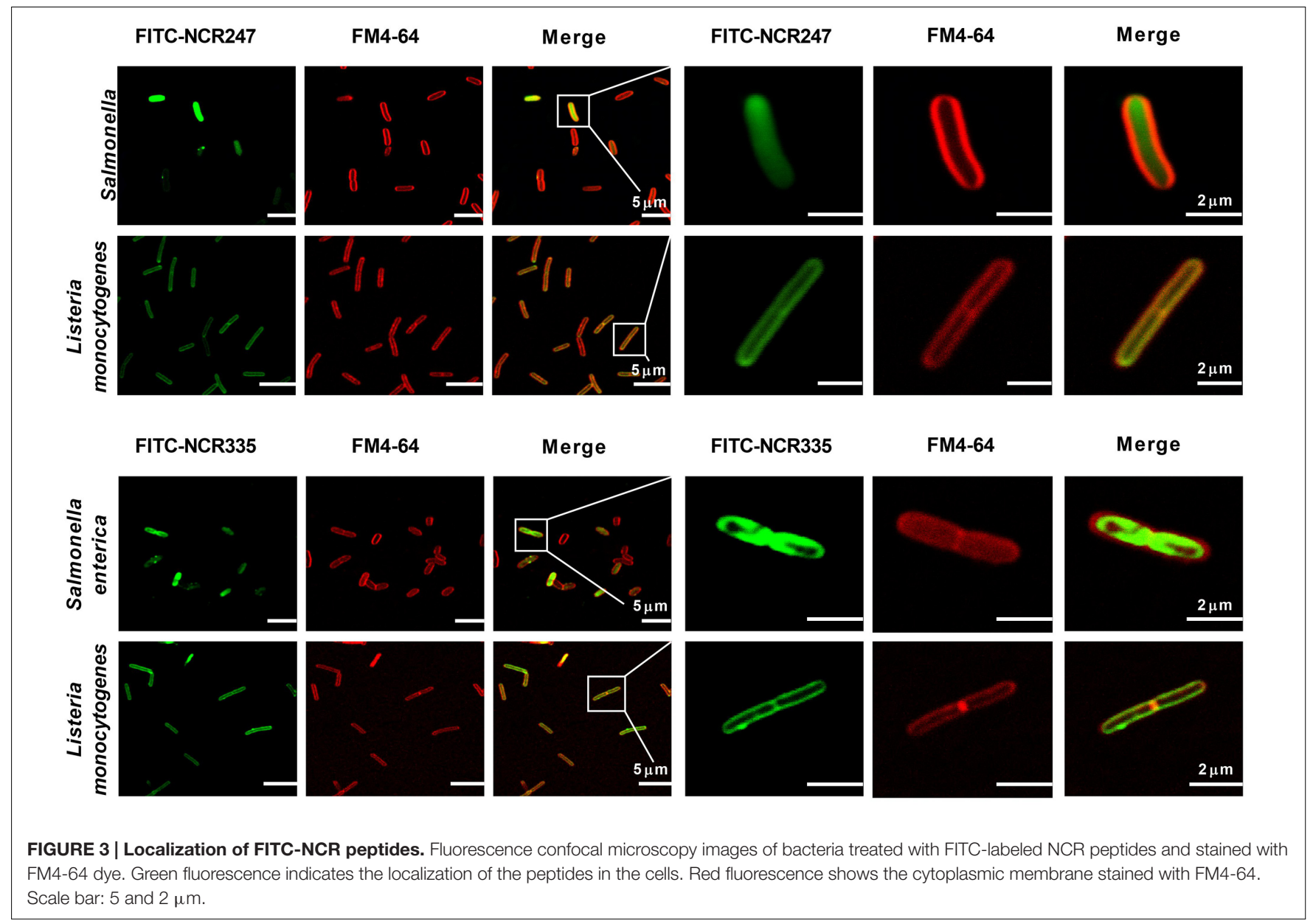

Antimicrobial peptides usually have a molecular mass less than $10 \mathrm{kDa}$ and contain $2-8$ positively charged amino acids, such as lysine and arginine that define their net positive charge at physiological pH. Furthermore, AMPs consist of up to $50 \%$ hydrophobic amino acids contributing to the amphipathic conformation when interacting with the target cell and binding to the membrane surface (Peters et al., 2010; Bahar and Ren, 2013). The outer membrane is the first interactor and the main target of the AMPs. Various modes of action have been described including membrane permeabilization through pore formation and membrane micellization in a detergent-like way (Shai, 1999). A number of studies reported that an increased membrane permeability alone might not be sufficient to cause cell death. AMPs also target intracellular compartments, such as various enzymes and ribosomes. Computational studies represent an integral part of AMP investigations. Several comparative analyses have demonstrated that AMPs have common motifs which correlate with specific parameters of their biological activity. These methods are based on peptide characteristics, such as primary sequence, charge, hydrophobicity, amphipathicity, size, and structure in order to obtain representative and relevant information on the relative contribution of each property to the peptide's biological activity. Computational sequence analysis was used to determine the basic AMP characteristics of the legume peptides NCR247 and NCR335. Lysine and arginine positively charged amino acid residues are especially abundant in NCR247 and NCR335. Arginines are highly concentrated at the C-terminal part of NCR247. The high number of lysine and arginine residues is consistent with the cationic nature of AMPs (Brogden, 2005). Most cationic peptides have a positive net charge ranging from +2 to +9 . Upon interaction with the membrane they bind to the lipid-peptide interface evolving strong electrostatic linkage with the negatively charged bacterial phospholipid membranes (Yount et al., 2006). NCR335 has one of the highest positive net charge $(+14)$ among legume NCRs, while NCR2 247 has a net charge of +6 . The majority of AMPs have a net charge ranging from +4 to +6 , which represent an optimal charge for biological activity (Tossi et al., 2000; Giangaspero et al., 2001). Various studies pointed out that net charge and positively charged residues significantly affect the antimicrobial activity of $\alpha$-helical AMPs (Tossi et al., 2000; Dathe et al., 2001; Giangaspero et al., 2001). Jiang et al. showed that decreasing the net charge on $\mathrm{V} 13 \mathrm{~K}$ analogs (less than +4 ) made the peptide inactive, while an increase in net charge from +4 to +8 resulted in higher antimicrobial activity and lower level hemolytic activity. However, further increase of net charge to +9 and +10 made the peptide more toxic (Jiang et al., 2008). Based on our present results and previous reports, it seems 

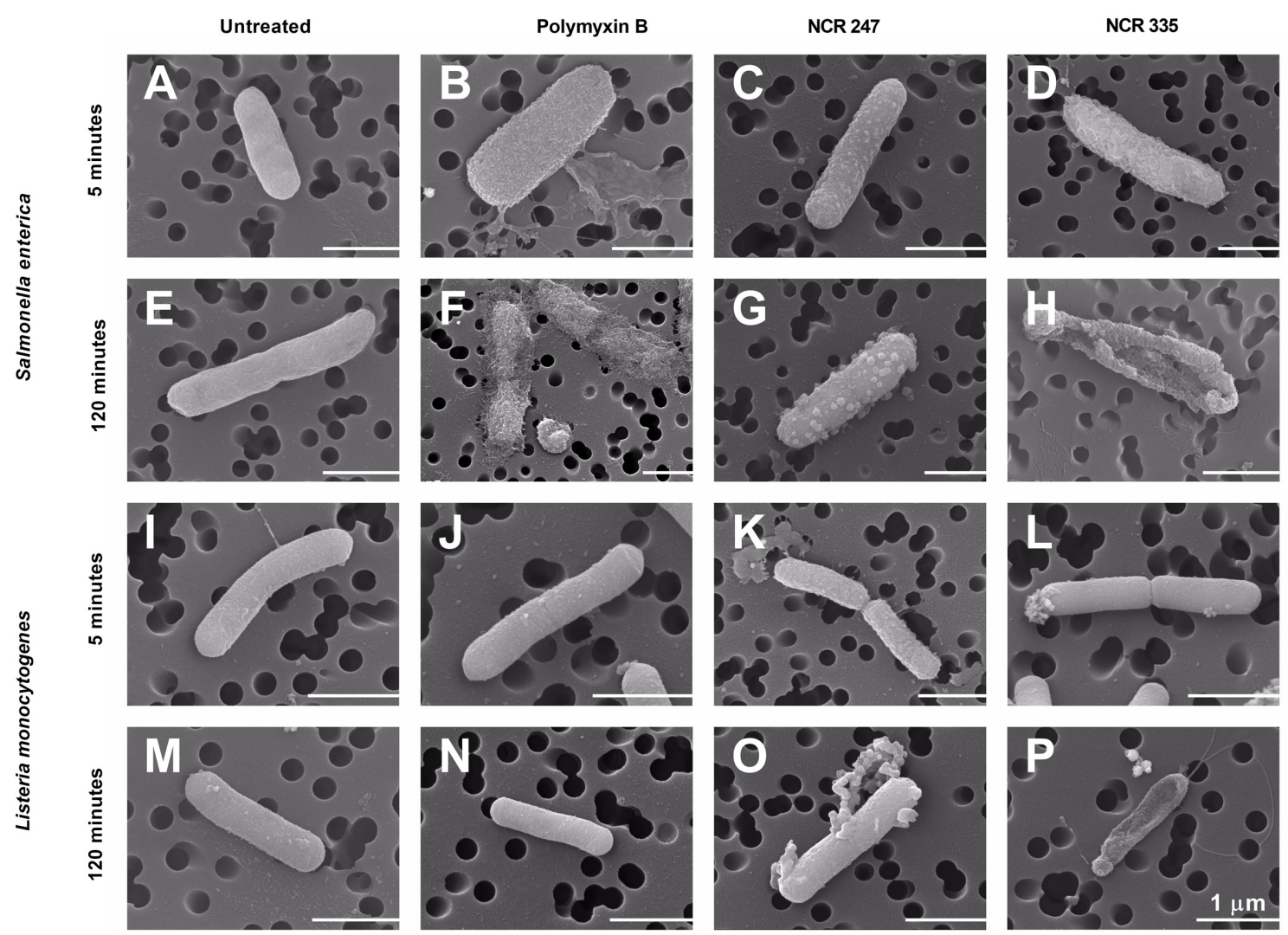

FIGURE 4 | Scanning electron microscopy investigations of peptide-treated S. enterica and $\mathbf{L}$. monocytogenes. Untreated bacterial membranes were intact (A,E,I,M). Blisters were observed on the cell surface of S. enterica treated with NCR247 for 5 min (C), while bleb-like structures appeared on the Salmonella cells after 2 h NCR247 treatment (G). NCR335 and polymyxin B treatments for 5 min resulted in wrinkly surface on S. enterica (B,D), while 2 h treatments with these peptides caused complete lysis of $S$. enterica cells $\mathbf{( F , H ) . ~ L . ~ m o n o c y t o g e n e s ~ w a s ~ s h o w n ~ t o ~ b e ~ f u l l y ~ r e s i s t a n t ~ t o ~ p o l y m y x i n ~ B ~ ( J , N ) , ~ w h i l e ~} L$. monocytogenes cells treated with NCR247 and NCR335 showed rough surface after 5 min treatment $(\mathbf{K}, \mathbf{L})$. Cell content was released and debris was visible around $L$. monocytogenes cells after $2 \mathrm{~h}$ treatment with NCR247 and NCR335 (O,P). Scale bar: $1 \mu \mathrm{m}$.

that NCR247 a good candidate for antimicrobial agent exerting antimicrobial activity without toxicity (Tiricz et al., 2013; Farkas et al., 2014). NCR335 has an especially high net charge explaining its strong antimicrobial activity. However, this peptide likely has a toxic effect on eukaryotic cells. Peptide hydrophobicity is also an important parameter for biological activity. Hydrophobicity is defined as the percentage of hydrophobic residues within a peptide, this value is around $50 \%$ for AMPs (Tossi et al., 2000; Yount et al., 2006). Two general requirements in terms of hydrophobicity have to be fulfilled by a membrane-lytic peptide: the peptide has to be soluble in water to enable rapid transport to the target microbes (low hydrophobicity required) and at the same time the peptide has to interact with the hydrophobic region of the bilayer in order to disturb the membrane structure and provoke permeability (high hydrophobicity required) (Dathe and Wieprecht, 1999). The total hydrophobic ratios of 29 and $37 \%$ for NCR247 and NCR335, respectively, is optimal for the peptides to attach to the membrane bilayer and to form hydrophobic moment to depolarize the membrane. Cysteine residues are abundant in the $\beta$-folded AMP family and these amino acids are important in terms of both structure and activity of these peptides. Cysteine amino acids are known to form disulfide bonds that confer stability to the peptide. Clear enrichment of cysteines was observed in both NCRs tested. The four cysteines form two disulfide bridges in NCR247 (Haag et al., 2011) and NCR335. The exact natural structure of NCRs disulphide bridges and their specific roles in the antimicrobial activity of the peptides are mostly unknown. It was shown for NCR247 that either cysteine replacements or the modifications of disulphide bonds altered the antimicrobial activity of the peptide at least against Sinorhizobium meliloti (Haag et al., 2012).

Bioinformatics prediction tools might be useful for largescale screening and identification of novel potential AMPs. The Collection of Anti-Microbial $\left(\mathrm{CAMP}_{\mathrm{R} 3}\right)$ database is an online server collecting information on sequence, protein definition, accession numbers, activity, source organism, target organisms, protein family. $\mathrm{CAMP}_{\mathrm{R} 3}$ currently has data on 10247 sequences, 757 structures, and 114 signatures present in 45 AMP families (Waghu et al., 2016). The database includes a prediction tool for AMP identification, this tool uses four models (SVM, RF, ANN, and DA). SVM, RF, and DA models each provides a probability score between 0 and 1 for the analyzed peptide sequence. Higher 
score represents greater possibility for the peptide to exert antimicrobial activity. In this study, the two natural NCR247 and NCR335 peptides clearly showed AMP characteristics and the prediction tool recognized NCR247 as true AMP by all four applied models, while NCR335 was predicted as AMP by two models (SVM and ANN).

Rapid killing of microbial targets is an important feature of AMPs. As reported here we determined the MIC, MBC, and $\mathrm{CE}$ values for two NCR peptides using a standard assay for MIC and MBC determination and another approach (drop plate method) for CE determination and further characterization of the antimicrobial features of the tested plant peptides. The killing effects of the two plant peptides were compared to those of two well described antimicrobials, the broad spectrum aminoglycoside antibiotic streptomycin (STM) and the peptide antibiotic PMB. STM is a protein synthesis inhibitor, it interrupts the ribosome cycle at the initiation of protein synthesis (Luzzatto et al., 1968). PMB alters bacterial outer membrane permeability by binding to a negatively charged site in the lipopolysaccharide layer (Velkov et al., 2010). After binding to lipopolysaccharide in the outer membrane of Gram-negative bacteria, polymyxins disrupt both the outer and inner membranes (Velkov et al., 2013). $\mathrm{PMB}$ is efficiently used against resistant Gram-negative infections as a last-line therapy while it has a weak or no effect on Grampositive pathogens. Interestingly, the two methods resulted in different results, which implies to the importance of the applied conditions when determining antimicrobial efficiency. In general, the peptides showed lower antimicrobial efficiency with the standard MIC and MBC determination method compared to that obtained using the drop-plate method resulting in the $\mathrm{CE}$ values. The main reason for the observed difference is the composition of the medium where the antimicrobial action takes place. The standard method uses the rich growth medium MHB containing divalent cations in high concentrations, while the treatment takes place in a low-salt medium in the drop plate method. The inhibition by divalent cations is a general feature of cationic AMPs. As results of the drop-plate method both S. enterica and L. monocytogenes were resistant to STM, PMB had antimicrobial effect only on the Gram-negative S. enterica, while NCR247 and NCR335 exerted significant antimicrobial effect against both food-borne pathogens. The killing effect of NCR335 was more pronounced, than that of NCR247, which is probably related to the higher positive net charge of NCR335. The observed bacterial resistance to STM using the drop-plate method is interesting and indicates that STM needs significantly longer time to exert its effect compared to the effect of NCR peptides.

The cationic NCR247 and NCR335 were shown to have high affinity to bind to the bacterial membranes (either Gram-negative or Gram-positive). Interestingly, the peptides showed intracellular, cytoplasmic localization only the Gramnegative $S$. enterica, while the peptides remained in the membrane of the Gram-positive L. monocytogenes as revealed by fluorescent microscopy. Both cytoplasmic and intramembrane accumulations suggested that NCR247 and NCR335 depolarized the bacterial membranes, which was confirmed by a live/dead staining assay. Beside the membrane disruptive effect, NCR247 and NCR335 modulate the bacterial synthetic processes (Tiricz et al., 2013; Farkas et al., 2014). Both NCRs had clear antimicrobial effect on the Gram-positive L. monocytogenes as well, while $\mathrm{PMB}$ proved to be ineffective against this pathogen. Scanning electron microscopy has demonstrated the differential membrane effect of the two NCR peptides. Treatment of the Gram-negative S. enterica and the Gram-positive L. monocytogenes with NCR247 and NCR335, respectively, resulted in different membrane morphology. Blisters, bleb-like membrane surface changes, irregular-wrinkled membrane stacks, deep craters and bursts, lysed cells were clearly observed in the SEM micrographs. The results indicated different interactions of NCR247 and NCR335 with the S. enterica membrane. In response to NCR247 treatment at $0.5 \times \mathrm{CE}$ the Salmonella outer membrane was destabilized instantly and the peptide penetration resulted in blisters and later bleb-like structures as observed in the SEM micrographs. Firstly, the NCR247 peptide induced leakage of the inner membrane appearing as small blisters. As a next step complete disruption of the inner membrane and the release of the cell content into the periplasmic space were observed in response to NCR247 treatment. NCR335 treatment of S. enterica at $0.5 \times$ CE resulted in cells with slightly wrinkled cell wall. Salmonella cells with rough surface were observed after 5 min treatment, while widespread cell lysis was detected after $2 \mathrm{~h}$ of treatment. The original rod-shaped morphology of $S$. enterica has been lost and deep bruises appeared on the cell surface. The wrinkled and rough surface and the deformation of the cell shape and cell wall can be associated with membrane permeabilization and the release of cell plasma. The effect of PMB on the Salmonella cell surface was similar to the effect of NCR335 suggesting similar mechanism of action. The Gram-positive L. monocytogenes was fully resistant to $\mathrm{PMB}$, no signs of any antimicrobial effect could be observed by SEM as well. The SEM investigation revealed interesting differences between the untreated Listeria samples and the peptide treatments. While the untreated cells and the PMB treated cells displayed normal smooth cell surface, the cells treated by NCR peptides (either NCR247 or NCR335) showed a slightly rough surface with small blisters even after $5 \mathrm{~min}$ incubation. The effect of NCR335 was more pronounced than that of NCR247, which corroborated with the antibacterial effects of these peptides. Bulges of intracellular cell debris were observed after 5 min NCR335 treatment at $0.5 \times \mathrm{CE}$ and total cell lysis was detected after $2 \mathrm{~h}$ incubation. NCR247 also induced cell degradation which was confirmed by the appearing blebs and intracellular material around the bacteria after 5 min of treatment.

Extensive membrane damage is a key factor in the inactivation of bacteria by AMPs. Experimental investigations supported by computational analysis confidently classified and demonstrated the antimicrobial nature of two $M$. truncatula NCR peptides. The highly cationic NCR247 and NCR335 plant peptides efficiently eliminated Gram-negative and Gram-positive foodborne pathogenic bacteria. The peptides were shown to disrupt the physical structure of the bacterial cell by increasing membrane permeability through pore formation. 


\section{AUTHOR CONTRIBUTIONS}

GM and AF designed and executed the experiments as well as composed the manuscript. AK and EK added useful recommendations and edited the manuscript.

\section{FUNDING}

Work in our laboratories was supported by the "SYM-BIOTICS" Advanced Grant of the European Research Council to EK (grant

\section{REFERENCES}

Alunni, B., Kevei, Z., Redondo-Nieto, M., Kondorosi, A., Mergaert, P., and Kondorosi, E. (2007). Genomic organization and evolutionary insights on GRP and NCR genes, two large nodule-specific gene families in Medicago truncatula. Mol. Plant. Microbe Interact. 20, 1138-1148. doi: 10.1094/MPMI-20-9-1138

Bahar, A. A., and Ren, D. (2013). Antimicrobial peptides. Pharmaceuticals 6, 1543-1575. doi: 10.3390/ph6121543

Balouiri, M., Sadiki, M., and Ibnsouda, S. K. (2016). Methods for in vitro evaluating antimicrobial activity: a review. J. Pharm. Anal. 6, 71-79. doi: 10.1016/j.jpha. 2015.11.005

Benko-Iseppon, A. M., Galdino, S. L., Calsa, T., Kido, E. A., Tossi, A., Belarmino, L. C., et al. (2010). Overview on plant antimicrobial peptides. Curr. Protein Pept. Sci. 11, 181-188. doi: 10.2174/138920310791112075

Brogden, K. A. (2005). Antimicrobial peptides: pore formers or metabolic inhibitors in bacteria? Nat. Rev. Microbiol. 3, 238-250. doi: 10.1038/ nrmicro1098

Chen, C. Y., Nace, G. W., and Irwin, P. L. (2003). A 6x6 drop plate method for simultaneous colony counting and MPN enumeration of Campylobacter jejuni, Listeria monocytogenes, and Escherichia coli. J. Microbiol. Methods 55, 475-479. doi: 10.1016/S0167-7012(03)00194-5

Dathe, M., Nikolenko, H., Meyer, J., Beyermann, M., and Bienert, M. (2001). Optimization of the antimicrobial activity of magainin peptides by modification of charge. FEBS Lett. 501, 146-150. doi: 10.1016/S0014-5793(01)02648-5

Dathe, M., and Wieprecht, T. (1999). Structural features of helical antimicrobial peptides: their potential to modulate activity on model membranes and biological cells. Biochim. Biophys. Acta 1462, 71-87. doi: 10.1016/S00052736(99)00201- 1

Epand, R. M., and Vogel, H. J. (1999). Diversity of antimicrobial peptides and their mechanisms of action. Biochim. Biophys. Acta 1462, 11-28. doi: 10.1016/S00052736(99)00198-4

Farkas, A., Maróti, G., Durgõ, H., Györgypál, Z., Lima, R. M., Medzihradszky, K. F., et al. (2014). Medicago truncatula symbiotic peptide NCR247 contributes to bacteroid differentiation through multiple mechanisms. Proc. Natl. Acad. Sci. U.S.A. 111, 5183-5188. doi: 10.1073/pnas.1404169111

Ganz, T. (2003). Defensins: antimicrobial peptides of innate immunity. Nat. Rev. Immunol. 3, 710-720. doi: 10.1038/nri1180

Giangaspero, A., Sandri, L., and Tossi, A. (2001). Amphipathic alpha helical antimicrobial peptides. Eur. J. Biochem. 268, 5589-5600. doi: 10.1046/j.14321033.2001.02494.x

Haag, A. F., Baloban, M., Sani, M., Kerscher, B., Pierre, O., Farkas, A., et al. (2011). Protection of sinorhizobium against host cysteine-rich antimicrobial peptides is critical for symbiosis. PLoS Biol. 9:e1001169. doi: 10.1371/journal.pbio.1001169

Haag, A. F., Kerscher, B., Dall'Angelo, S., Sani, M., Longhi, R., Baloban, M., et al. (2012). Role of cysteine residues and disulfide bonds in the activity of a legume root nodule-specific, cysteine-rich peptide. J. Biol. Chem. 287, 10791-10798. doi: $10.1074 /$ jbc.M111.311316

Hale, J. D., and Hancock, R. E. (2007). Alternative mechanisms of action of cationic antimicrobial peptides on bacteria. Expert Rev. Anti Infect. Ther. 5, 951-959. doi: 10.1586/14787210.5.6.951

Hancock, R. E., and Scott, M. G. (2000). The role of antimicrobial peptides in animal defenses. Proc. Natl. Acad. Sci. U.S.A. 97, 8856-8861. doi: 10.1073/pnas. 97.16 .8856 number 269067), by TÁMOP-4.2.4.A/2-11/1-2012-0001 (number A2-MZPDÖ-13-0038) and by the GINOP-2.3.2-15-2016-00011 grants supported by the European Union and the State of Hungary.

\section{ACKNOWLEDGMENT}

Authors wish to thank Tania Rosas Perez for the bioinformatics work.

Hancock, R. E. W., and Sahl, H. G. (2006). Antimicrobial and host-defense peptides as new anti-infective therapeutic strategies. Nat. Biotechnol. 24, 1551-1557. doi: $10.1038 / \mathrm{nbt} 1267$

Hasper, H. E., Kramer, N. E., Smith, J. L., Hillman, J. D., Zachariah, C., Kuipers, O. P., et al. (2006). An alternative bactericidal mechanism of action for lantibiotic peptides that target lipid II. Science 313, 1636-1637. doi: 10.1126/ science. 1129818

Hassan, M., Kjos, M., Nes, I. F., Diep, D. B., and Lotfipour, F. (2012). Natural antimicrobial peptides from bacteria: characteristics and potential applications to fight against antibiotic resistance. J. Appl. Microbiol. 113, 723-736. doi: 10. 1111/j.1365-2672.2012.05338.x

Herigstad, B., Hamilton, M., and Heersink, J. (2001). How to optimize the drop plate method for enumerating bacteria. J. Microbiol. Methods 44, 121-129. doi: 10.1016/S0167-7012(00)00241-4

Hilpert, K., McLeod, B., Yu, J., Elliott, M. R., Rautenbach, M., Ruden, S., et al. (2010). Short cationic antimicrobial peptides interact with ATP. Antimicrob. Agents Chemother. 54, 4480-4483. doi: 10.1128/AAC.01664-09

Horváth, B., Domonkos, Á, Kereszt, A., Szûcs, A., Ábrahám, E., Ayaydin, F., et al. (2015). Loss of the nodule-specific cysteine rich peptide, NCR169, abolishes symbiotic nitrogen fixation in the Medicago truncatula dnf7 mutant. Proc. Natl. Acad. Sci. U.S.A. 112, 3-8. doi: 10.1073/pnas.1500777112

Jenssen, H., Hamill, P., and Hancock, R. E. W. (2006). Peptide antimicrobial agents. Clin. Microbiol. Rev. 19, 491-511. doi: 10.1128/CMR.00056-05

Jiang, Z., Vasil, A. I., Hale, J. D., Hancock, R. E. W., Vasil, M. L., and Hodges, R. S. (2008). Effects of net charge and the number of positively charged residues on the biological activity of amphipathic alpha-helical cationic antimicrobial peptides. Biopolymers 90, 369-383. doi: 10.1002/bip.20911

Joerger, R. (2003). Alternatives to antibiotics: bacteriocins, antimicrobial peptides and bacteriophages. Poult. Sci. 82, 640-647. doi: 10.1093/ps/82. 4.640

Kang, C.-G., Hah, D.-S., Kim, C.-H., Kim, Y.-H., Kim, E., and Kim, J.-S. (2011) Evaluation of antimicrobial activity of the methanol extracts from 8 traditional medicinal plants. Toxicol. Res. 27, 31-36. doi: 10.5487/TR.2011.27.1.031

Kondorosi, E., Mergaert, P., and Kereszt, A. (2013). A paradigm for endosymbiotic life: cell differentiation of Rhizobium bacteria provoked by host plant factors. Annu. Rev. Microbiol. 67, 611-628. doi: 10.1146/annurev-micro-092412155630

Lecuit, M. (2007). Human listeriosis and animal models. Microbes Infect. 9, 1216 1225. doi: 10.1016/j.micinf.2007.05.009

Lobo, D. S., Pereira, I. B., Fragel-Madeira, L., Medeiros, L. N., Cabral, L. M., Faria, J., et al. (2007). Antifungal Pisum sativum defensin 1 interacts with Neurospora crassa cyclin F related to the cell cycle. Biochemistry 46, 987-996. doi: $10.1021 /$ bi061441j

Löfström, C., Hansen, T., Maurischat, S., and Malorny, B. (2016). "Salmonella: Salmonellosis," in Encyclopedia of Food and Health, eds B. Caballero, P. Finglas and F. Toldra (Cambridge, MA: Academic Press), 701-705. doi: 10.1016/B9780-12-384947-2.00607-3

Luzzatto, L., Apirion, D., and Schlessinger, D. (1968). Mechanism of action of streptomycin in E. coli: interruption of the ribosome cycle at the initiation of protein synthesis. Proc. Natl. Acad. Sci. U.S.A. 60, 873-880. doi: 10.1073/pnas. 60.3.873

Manners, J. M. (2007). Hidden weapons of microbial destruction in plant genomes. Genome Biol. 8, 225. doi: 10.1186/gb-2007-8-9-225 
Maróti, G., Kereszt, A., Kondorosi, É, and Mergaert, P. (2011). Natural roles of antimicrobial peptides in microbes, plants and animals. Res. Microbiol. 162, 363-374. doi: 10.1016/j.resmic.2011.02.005

Mergaert, P., Nikovics, K., Kelemen, Z., Maunoury, N., Vaubert, D., Kondorosi, A., et al. (2003). A novel family in Medicago truncatula consisting of more than 300 nodule-specific genes coding for small, secreted polypeptides with conserved cysteine motifs. Plant Physiol. 132, 161-173. doi: 10.1104/pp.102. 018192

Mergaert, P., Uchiumi, T., Alunni, B., Evanno, G., Cheron, A., Catrice, O., et al. (2006). Eukaryotic control on bacterial cell cycle and differentiation in the Rhizobium-legume symbiosis. Proc. Natl. Acad. Sci. U.S.A. 103, 5230-5235. doi: $10.1073 /$ pnas.0600912103

Nallu, S., Silverstein, K. A. T., Zhou, P., Young, N. D., and Vandenbosch, K. A. (2014). Patterns of divergence of a large family of nodule cysteine-rich peptides in accessions of Medicago truncatula. Plant J. 78, 697-705. doi: 10.1111/tpj. 12506

Ördögh, L., Vörös, A., Nagy, I., Kondorosi, É, and Kereszt, A. (2014). Symbiotic plant peptides eliminate candida albicans both in vitro and in an epithelial infection model and inhibit the proliferation of immortalized human cells. Biomed. Res. Int. 2014, 9. doi: 10.1155/2014/320796

Perron, G. G., Zasloff, M., and Bell, G. (2006). Experimental evolution of resistance to an antimicrobial peptide. Proc. Biol. Sci. 273, 251-256. doi: 10.1098/rspb. 2005.3301

Peters, B. M., Shirtliff, M. E., and Jabra-Rizk, M. A. (2010). Antimicrobial peptides: primeval molecules or future drugs? PLoS Pathog. 6:e1001067. doi: 10.1371/ journal.ppat. 1001067

Roux, B., Rodde, N., Jardinaud, M. F., Timmers, T., Sauviac, L., Cottret, L., et al. (2014). An integrated analysis of plant and bacterial gene expression in symbiotic root nodules using laser-capture microdissection coupled to RNA sequencing. Plant J. 77, 817-837. doi: 10.1111/tpj.12442

Sass, V., Schneider, T., Wilmes, M., Körner, C., Tossi, A., Novikova, N., et al. (2010). Human $\beta$-defensin 3 inhibits cell wall biosynthesis in staphylococci. Infect. Immun. 78, 2793-2800. doi: 10.1128/IAI.00688-09

Sels, J., Mathys, J., De Coninck, B. M. A., Cammue, B. P. A., and De Bolle, M. F. C. (2008). Plant pathogenesis-related (PR) proteins: a focus on PR peptides. Plant Physiol. Biochem. 46, 941-950. doi: 10.1016/j.plaphy.2008. 06.011

Shai, Y. (1999). Mechanism of the binding, insertion and destabilization of phospholipid bilayer membranes by-alpha-helical antimicrobial and cell nonselective membrane-lytic peptides. Biochim. Biophys. Acta 1462, 55-70. doi: 10.1016/S0005-2736(99)00200-X

Shai, Y. (2002). Mode of action of membrane active antimicrobial peptides. Biopolymers 66, 236-248. doi: 10.1002/bip.10260

Silverstein, K. A. T., Moskal, W. A., Wu, H. C., Underwood, B. A., Graham, M. A., Town, C. D., et al. (2007). Small cysteine-rich peptides resembling antimicrobial peptides have been under-predicted in plants. Plant J. 51, 262-280. doi: 10.1111/ j.1365-313X.2007.03136.x
Thomas, S., Karnik, S., Barai, R. S., Jayaraman, V. K., and Idicula-Thomas, S. (2009). CAMP: a useful resource for research on antimicrobial peptides. Nucleic Acids Res. 38, D774-D780. doi: 10.1093/nar/gkp1021

Tiricz, H., Szücs, A., Farkas, A., Pap, B., Lima, R. M., Maróti, G., et al. (2013). Antimicrobial nodule-specific cysteine-rich peptides induce membrane depolarization-associated changes in the transcriptome of Sinorhizobium meliloti. Appl. Environ. Microbiol. 79, 6737-6746. doi: 10.1128/AEM.01791-13

Tossi, A., Sandri, L., and Giangaspero, A. (2000). Amphipathic, alpha-helical antimicrobial peptides. Biopolymers 55, 4-30. doi: 10.1002/1097-0282200055: $1<4::$ AID-BIP30>3.0.CO;2-M

Van de Velde, W., Zehirov, G., Szatmari, A., Debreczeny, M., Ishihara, H., Kevei, Z., et al. (2010). Plant peptides govern terminal differentiation of bacteria in symbiosis. Science 327, 1122-1126. doi: 10.1126/science.1184057

Velkov, T., Roberts, K. D., Nation, R. L., Thompson, P. E., and Li, J. (2013). Pharmacology of polymyxins: new insights into an "old" class of antibiotics. Future Microbiol. 8, 1-20. doi: 10.2217/fmb.13.39.Pharmacology

Velkov, T., Thompson, P. E., Nation, R. L., and Li, J. (2010). Structure-activity relationships of polymyxin antibiotics. J. Med. Chem. 53, 1898-1916. doi: 10. 1021/jm900999h

Waghu, F. H., Barai, R. S., Gurung, P., and Idicula-Thomas, S. (2016). CAMPR3: a database on sequences, structures and signatures of antimicrobial peptides. Nucleic Acids Res. 44, D1094-D1097. doi: 10.1093/nar/gkv1051

Waghu, F. H., Gopi, L., Barai, R. S., Ramteke, P., Nizami, B., and Idicula-Thomas, S. (2014). CAMP: collection of sequences and structures of antimicrobial peptides. Nucleic Acids Res. 42, D1154-D1158. doi: 10.1093/nar/gkt1157

Wang, G., Li, X., and Wang, Z. (2016). APD3: the antimicrobial peptide database as a tool for research and education. Nucleic Acids Res. 44, D1087-D1093. doi: $10.1093 / \mathrm{nar} / \mathrm{gkv} 1278$

Wiegand, I., Hilpert, K., and Hancock, R. E. W. (2008). Agar and broth dilution methods to determine the minimal inhibitory concentration (MIC) of antimicrobial substances. Nat. Protoc. 3, 163-175. doi: 10.1038/nprot.2007.521

Yount, N. Y., Bayer, A. S., Xiong, Y. Q., and Yeaman, M. R. (2006). Advances in antimicrobial peptide immunobiology. Biopolymers 84, 435-458. doi: 10.1002/ bip. 20543

Zasloff, M. (2002). Antimicrobial peptides of multicellular organisms. Nature 415, 389-395. doi: 10.1038/415389a

Conflict of Interest Statement: The authors declare that the research was conducted in the absence of any commercial or financial relationships that could be construed as a potential conflict of interest.

Copyright (c) 2017 Farkas, Maróti, Kereszt and Kondorosi. This is an open-access article distributed under the terms of the Creative Commons Attribution License (CC BY). The use, distribution or reproduction in other forums is permitted, provided the original author(s) or licensor are credited and that the original publication in this journal is cited, in accordance with accepted academic practice. No use, distribution or reproduction is permitted which does not comply with these terms. 